\title{
POSTTRAUMATIC STRESS DISORDER IN JESS WALTER'S THE ZERO
}

\author{
Eman Saud Thannoon \\ M.A. Scholar, University of Baghdad/College of Education/Ibn Rushd
}

DOI: $10.37648 / \mathrm{ijrssh.v10i01.026}$

Received:04 ${ }^{\text {th }}$ October 2019; Accepted:23 $3^{\text {rd }}$ November, 2019; Published: 04 ${ }^{\text {th }}$ December, 2019

\begin{abstract}
The eventual attacks of 9/11 in America, on the World Trade Center at Ground Zero, had changed the world and brought disastrous problems to a lot of civilians. Many people lost their lives; others were traumatized. The event reveals the hidden aspect of the States and its assistants. The paper examines the behavior of traumatized individuals in relation to society that trauma involves both. The socio cultural approach will achieve the goal. It studied the responses of the individuals to the event and the motives behind these reactions. Jess Walter, a member of a domestic group of writers has introduced a comedy-a special type of comedy as a criticism to the political system of America within the time of terrorism. Through the portrayal of the characters, Walter tries to present a vivid image to what happened during the time of the attack and aftermath. PTSD is a trail which is left by a traumatic event
\end{abstract}

Key Words:eventual, disastrous, terrorism, PTSD, traumatized, socio cultural.

\section{INTRODUCTION}

The beginning of the twenty-first century is alarmingly marked by unprecedented of the tragic attacks of 9/11 and their sweeping; local and global. The world has almost changed unexpectedly aftermaths. The date, therefore, marks a turning point in history. 9/11 puts American people in a situation that they never forget. The event creates trauma which is un-healable. It also gives historical significance to Ground Zero, the area where the attacks occurred. The incident is not only American; on the contrary, it is an international calamity and global catastrophe. The $9 / 11$ event is the most dangerous and strongest among those which happened previously such as the genocide of Holocaust, Hiroshima, Cambodia, WW1,WW11, and the cold war (Ann 16).
The fact is that the American society is a multicultured society. Since the establishment of America till now, multiculturalism accompanied it. The immigrant Muslims and non-Muslims, The Irish, Indians, Germans, and Europeans have settled in the United States. At about the end of the 20th century and early 21st, geopolitics has become a dominant part of the ideologies all over the world. America, the most powerful country has got the global supremacy and universality. The rising power of America justifies the idea of hegemony and domination, it is marked by "the ideological need to consolidate and justify domination in cultural terms that has been the case of the world since the nineteenth century" (Said 28).

However, the term "Terrorism" emerged during the 19th century, especially, the French revolution era which is called "la Terreur". With the great development in technology within the 20th century, 
the notion becomes more popular that is used by authorities and mass media. It is culminated in the term "The War on Terror" which indicates activism. "Terrorism" is defined by Chambers Dictionary as "the systematic use of violence and intimidation to force a government or community " (893). The psychological and tragic influence caused by a terrorist attack is described as trauma and the persons who are wounded are labeled as traumatized (Seeley 17).

Though the attack took place in 2001, it is still a live memory in peoples' minds all over the world and one of the main topics in many books, journals, scholar articles, novels, films, ...etc. In the field of art, for instance, the alternative world is created by using the power of imagination by many novelists who have written their literary works post $9 / 11$ as a response to the tragic situation which most of its reasons are till now uncertain. Post 9/11 writers are of two major groups; with and against Muslims. Those who are with Muslims, prove the innocent of Muslims through their works such as Laila Halaby and Mohsin Hamid. While writers against Muslims prove the involvement of Muslims in the terrorist attacks like Don DeLillo, KenKalfus, Jess Walter, and others.

Jess Walter (1965) is a member of against Muslim group of writers. $\mathrm{He}$ is a journalist and reporter. He describes himself, saying: "a writer" to whom "the subject is less important than the act of writing itself" (Walter: Interview, Web.). As an ambitious man, Walter starts writing novels which are published in many countries and translated into many languages. In The Zero, he presents his protagonist as the one who acts out trauma because he is a firsthand witness in the situation. Remy relives and re-experiences the event mentally and this is vivid through his relationship with his wife, son, and the two girlfriends. The novel is built upon two contrastive powers; good versus evil; peace versus war.

Since trauma is a global phenomenon, it afflicts all people in society. Novelists are the first who felt the influence of terrorism that they manage to depict reality in their works. They "tell and retell the story of their traumatic experience" (Tal 137). So writers about trauma and posttraumatic stress disorder (PTSD) use their narratives as a means to translate the meaningless fragmentations into a meaningful language to illustrate the real life of modern societies. They create their characters as victims to the event and make them suffer throughout their life and their suffering is originally psychological. Literature, according to Animest Roy, "might prove to be a useful and potent tool" (2). So authors give solution through fiction and make use of literature as a healer.

\section{TRAUMA THEORY}

The contemporary trauma theory emerged in the 1960s for social demands such as war violence, crimes of abuse, and genocide. It helps in studying the psychological aspect of those who experience a terrorist event. Trauma theory aims at reinforcing the bridge between what is theoretical and practical (Kocak 26). The contextualization of trauma discourses is dealt with by Michelle Balaev as related to location. Thus, the place has a fundamental influence on the traumatized individuals and community as well. The discourses include culture, religion, identity, and history. (149). So the trauma caused by the $9 / 11$ incident should be studied according to the site.

To apply trauma theory on the $9 / 11$ event is to study psychology first and then sociology. Cathy Caruth's perspective of psychoanalysis, concerning trauma, is that she considered trauma as an act and the response of the individuals is the opposite to this act (3). Trauma, according to her, is an "unsolvable problem of the conscious that illuminates the inherent contradictions of experience and language" (117118). This view is basically Freudian. When a traumatized person has constructed trauma in his mind, he ought to express it in different contexts of behavior outside the memory that trauma has no fixed space or position (iv).

Accordingly, the identity of the community comes to a sense either to settle down or to be ruptured. Thus, the psychological aspect is a part of the social field and the shift is from psychology into sociology (Randall 121). The sociologist Kia Erikson states 
two types of trauma; personal and cultural. $\mathrm{He}$ declares that people, even they did not witness the incident of 9/11 might be traumatized and that "9/11 is a rapture of everybody" (14). He concludes that trauma is a painful memory and the brain cannot perceive it fully at the moment. So the response of the individuals is to define that painful situation. Trauma, to him, needs a time span to be felt. In this, he agrees with Caruth's argument about the idea of belatedly (18).

\section{METHODOLOGY}

To understand the effect of trauma and the PTSD is to investigate the psychological and social nature of the traumatized people and society. The sociocultural approach which is established by Lev Vygtsky in the 20 s of the $20^{\text {th }}$ century may achieve the purpose. The approach is mostly used in psychology to examine the mental process and in sociology to search for the social behavior which is determined by culture and social needs. How the individual interacts and copes with others and with his/her surroundings. Therefore, the method becomes a matter of concern for many scholars and researchers in literature. In her book, Social Psychology (2010), Catherine A. Sanderson describes "peoples' behavior" as "shaped in part by their social and/or cultural contact" (13).

Environmental surroundings; culture and society, are of great significance to the post $9 / 11$ novelists who try to convey reality through literature. They manage to create a sense of sympathy within the reader, make him/her participate in the text, and give a background to the event. This is done through the link between what is in the mind of the character with what is happening outside. The different responses of individuals of multi cultured society, the clash of religion and civilization, and the interaction of the characters with their surroundings are aspects to be examined through the sociocultural approach which is a modernist theory that shows how experience makes people act. It is based on the idea that all types of behavior are acquired through conditioning, and conditioning occurs through the interaction with the surrounding.

\section{TRAUMA \& PTSD}

Looking back to psychology, the psychologist Sigmund Freud $\left(19^{\text {th }}\right.$ century), suggests that trauma is the second face to what is called "hysteria". According to one of his studies, mentioned in his book, Project for Scientific Psychology (1895), he concludes that actual trauma consists of two main stages: the earlier which appears during childhood, meaningless but has sexual contexts; the later appears in adulthood, which has no sexual contexts but sexual meaning (120). Freud, thus, assumes that the dialectic relation between these two stages is the main cause to create actual trauma. This conclusion needs to be improved and modified according to real events for the following reasons: For example, during the WWI, many people are seen with mental or psychological neurosis. This is not conditioned to their actual participation in the battle field. However, most of them never took part as real participants. Similarly, the same effect can be seen during the WWII that trauma reappeared because of the stress and depression of the wars (130).

Trauma, according to sociology, is of two main types; personal/individual and collective/cultural. Erikson asserts that though trauma is created out of a sudden, it has no sudden influence. He defines individual trauma as "a blow to the tissues of the body... and the tissues of the mind". While collective trauma, according to him, is "a blow to the basic issues of social life that damages the bonds attaching people together and impairs the prevailing sense of community". Through these definitions, one can judge that Erikson finds the link between individuals and their society. $\mathrm{He}$ states that traumatized people obviously disbelieve the world around them, they feel everything is cruel and harsh. They find relief in guilt and as a result they become unprotected under a law.

The PTSD is a psychiatric disorder results from any threatening, painful, or traumatic event. Since the twenty-first century is stressful, in general, so the PTSD is a serious phenomenon to modern man. It involves many notions such as destruction, divorce, madness, violence, immigration, ...etc. All types lead to tragedy. The incident of $9 / 11$ 
caused not only trauma but, also, traumatic disorder. Theorists, like Professor Thomas McMilland, University of Glasgow, in his article, "Errors in Diagnosing Posttraumatic Stress Disorder", asserts that the impact of the fall of the two towers at Ground Zero, death of many people, the collapse of religion and civilization lead to create gaps in mind. These gaps need to be filled, either by flashbacks, nightmares, or fragmentations (40).

Another view is that the German Psychologist, Edith Jacobson focuses on the "process of regression" and the "sense of self" through her Revised Drive Theory concluding that low performance and pain are results of a tragic event (50). Neil Smelser, claims that collective trauma "is established within a prolonged, contested process in a socio cultural environment". Relatively, trauma afflicts individuals as it afflicts society and needs a system or order to define it according to social rules. It is regarded as social when it creates a kind of damage, disorder, and change the well-built society (144).

Post 9/11 trauma fiction deals with the event through narratives. It gives it meaning and creates certain themes such as anxiety, loss, ugliness, uncertainty. The danger of trauma does not mean the event itself but the sense of fear and shock that follows the event and the role of the author is to illustrate what the traumatizing situation means and what danger follows it (Alexander 10). The connection between trauma and literature is described by Caruth that "literature is interested in the complex relation between knowing and not knowing" (4). So survivals are to leave the burning buildings or return to their loving persons either. In her Trauma Fiction, Anne Whitehead characterizes trauma fiction as being interfering with postcolonial fiction. She argues that "in its concern with ... repressed and forgotten" (82). Trauma fiction is a description and representation of painful memories with damaging experience.

In The Zero, Walter narrates the event accurately creating characters stand for all people in America. The protagonist, ,Remy, is the embodiment of all traumatized individuals. He suffers gaps in mind that leads him to appear in a very weak and crack personality. He could not tell the truth, or observe the event, besides that he could not recognize things. In the beginning Remy lived in conflict, dissatisfaction, and anxiety. Later in the novel, he gets blind and becomes fully frustrated. He is now a split person once we see him as simple and innocent; other times reveals his terrorism. Walter portrays him as "fractured self" which makes a victim simply change into a terrorist person.

Because trauma does not appear immediately, but belatedly, Remy lacks the ability to describe things and identify the scenes. For example, "paper", which is a significant symbol in the novel, means to him many things: "ash", which means burnt paper; "burnt persons" that he said "they were bellowed and blown" (Walter 19). Also, the paper symbolizes a loud wind destroyed the twin towers. Unconsciousness is a sign of the PTSD. Remy describes the attacks of 9/11 as "silent firework". His condition is hard to heal, it is in fact a remarkable mark to the gradual loss of memory. Initially, when Remy awakened, he "finds himself wet but didn't remember rain" (4). Similarly, when he was invited to a meal, "he felt full but couldn't recall eating" (40).

Mostly, all of the characters in the novel suffer from a similar condition. They are obsessed, victimized, and split. Edgar, the son, for instance, pretending death to his father though he is still alive. Irony is everywhere in the novel. It is to stand for the policy of the States during the era of terrorism. Another character is Jaguar who is named by the CIA, a leader of the made-up cell. He bombed himself committing suicide at last. The mayor who is called The Boss, is the most Machiavellian character. He tried many times to accuse Remy of terrorism. His behavior is dual.

Walter has succeeded in portraying trauma and the PTSD as a long lasting effect resulted in a tragic event through the character of the protagonist. He makes the form go with the content. For example, when narrating the gaps in mind, he makes dashes stand for the meaning, "I'll be doing one thing and suddenly _" (148). "But I guess _" (226). "I'm looking forward to _" (22). The aim is to show how 
trauma is expanded throughout the life of the traumatized individuals. It changes the personal endurance into cultural and is dealt with according to the social cognitions.

\section{CONCLUSION}

The shell-shock of $9 / 11$ and aftermaths leads trauma to be arisen. Self-depression and memorial trauma turn out to be cultural in the form of divorce, madness, immigration, or suicide. Thus, Ground Zero becomes a spot of memorial trauma after 9/11; burning candles, raising flags, posting photographs on the walls, and so on. Therefore, the annual remembrance of private trauma is, with the passage of time, changed into cultural that trauma involves all people in New York City. Satire is the most common theme in the works of the authors of post 9/11. It criticizes the leaders who are disable to maintain their responsibilities. The novel is full of absurd situations and ironies. One of the concepts of trauma theory is PTSD which is shown in the novel in various ways such as fragmentations, gaps, divorce, danger, duality, ...etc. The characters are allegories of all people of modern societies. The Zero describes crucial moments in the current American history. It introduces a counter-narrative to the States in general, and particularly, the Bush administration. The novel is elaborated by Walter through its well-built action. It is an open end novel gives the reader a chance to participate in the text; he/she can add, omit, or change. It is multi-voiced, dialogized, regenerative, and inclusive.

\section{WORK CITED}

Alexander, Jeffrey. Cultural Trauma and Collective Identity.Berkeley, Calf; London: California UP, 2004. Print.

Ann, Lefevre. Sociocultural Mechanism Associated with Posttraumatic Stress Disorder. Maryland UP, 2011. Print.

Balaev, Michelle (ed.). Contemporary Approach in Literary Trauma. ISBN. Amazon. Com. 2014
Chambers, William \& Robert. "Terrorism". The Chambers Dictionary. $\quad 9^{\text {th }}$ ed. UK. 2006. www.chambers.com.uk.

Erikson, Kia. Notes on Trauma and Community. Hopkins UP. 1995. Print.

Freud, Sigmund. "Remembering, Repeating, and Writing-Through". Collected Papers. London: Hogarth Press. 1995. Print.

Kocak, Betul A. Language and Cultures in Contact. University of Salamanca. PhD. Thesis. 2015. PDF.

McMilland, T. M. "Errors in Diagnosing Posttraumatic Stress Disorder". Brain Injury. Journal of NeurologyAnd Psychiatry. 39-46, 15(2001).

Randall, Martin. 9/11 and The Literature of Terror. Edinburgh UP. 2015. Print.

Roy, Animest. "Green Poems". MIT International Journal of English Language\& Literature.1, 2(2014).

Said, Edward. Culture and Impressionism. NY: Vintage Books, 1993. Print.

Sanderson, A. Catherine. Social Psychology. $1^{\text {st }}$ ed. Dublin: Ireland. 2009. Print.

Seeley, Caren. Therapy After Terror. NY: Cambridge UP, 2008.

Tal, Kali. Worlds of Hurt: Reading the Literature of Trauma. NY: Cambridge UP. 1996.

Walter, Jess. The Zero. Harper Collins Productions. 2007. Print.

\section{_ _ _, http://www.amazon.com>Jess-Walter- interview.}

Whiteman, Anne. Trauma History. Edinburgh UP. 2004. Print. 